развития тогдашнего права. Законодатель в Литовском Уставе 1529 г. предусмотрел новые для уголовного права принципы и продолжил развивать предыдущие, в частности, на законодательном уровне было провозглашено равенство всех свободных людей перед законом, привлечение к ответственности только в судебном порядке и индивидуализация наказания.

Ключевые слова: Литовский Устав 1529 г., уголовное право, имущественные наказания, головщина.

Yatsyshyn M. Innovations in the General Provisions of Criminal Law and Property Penalties under the First Lithuanian Statute of 1529. The article considers the rules of criminal law and the principles of the administration of justice, set out in the Lithuanian Statute of 1529. The first Lithuanian of 1529 was based on the provisions of Rus'ka Pravda, the norms of Common law, and a number of articles from the Polish and German Codes of law. The provisions of criminal law were lodged in chapters twelve and thirteen of the Statute of 1529, however other Statute chapters also contained certain norms of the criminal law. The study of the issues regarding the innovations in the general provisions of the criminal law allows to conclude that the norms of the Old Lithuanian Statute have incorporated the humanistic ideas of equality before the law, but in practice, the implementation of these norms remained unrealized. With regard to the property punishments, the study has revealed an innovative form of punishment - holovshchyna (in Rus'ka Pravda a fine for the «head of the killed» paid to the family or his relatives). However, it was applied only as an additional or supplementary one. The first Statute of the Grand Duchy of Lithuania in its norms had significant progress in the process of systematization and codification of medieval criminal law not only in Ukraine but in Europe too. During the development of the Statute, such complex theoretical and practical issues as the division of legal norms by branches and their placement in a certain system were resolved for the first time. Although the Statute of 1529 provided for the saving of privileges in the field of criminal law for the ruling classes, but its norms proclaimed the general rule of law, which, of course, was a significant step for the development of law at that time. The legislator in the Statute of 1529 contained new principles for criminal law and continued to develop the previous ones, such as the equality of all free people according the law, which was proclaimed at the legislative level, prosecution only in the court and individualization of punishment.

Key words: Lithuanian Statute of 1529, criminal law, property penalties, holovshchyna.

УДК : 342.7 (093)

DOI https://doi.org/10.32782/2409-4544/2019-2/2

С. Булавіна

\title{
Генеза гарантій прав та свобод людини й громадянина в Україні: історико-правове дослідження
}

У статті досліджено історико-правову думку про гарантії прав і свобод людини та громадянина. Досліджено становлення та розвиток ідеї гарантій прав і свобод людини та громадянина в України. У вітчизняній скарбниці історико-правових досліджень проблематики прав і свобод людини та їх гарантій гідне місце займає спадщина Павла Русина (1450-1517рр.). Цікавими та прогресивними ідеями, які сприяють закріпленню прав і свобод людини, насичена творчість типового представника українського гуманістичного руху першої половини XVIст. - філософа, історика та політолога Станіслава Оріховського-Роксолана (1513-1566 рр.). Одним з перших серед вітчизняних мислителів Інокентій Гізель (1600-1683 рр.) поставив природне право як критерій людської поведінки вище від закону Божого, доповнюючи критерій добра і зла розумом, який, пізнавши закони природи, керує вчинками людини відповідно до цих законів. Встановлено, що на державу та ії органи Конституція і закони України покладають обов'язки по забезпеченню прав і свобод людини та громадянина. Так, у ст. 3 Конституції України визначено головний зміст та спрямованість діяльності держави - права і свободи людини та їх гарантії. Історико-правові ідеї, висунуті видатними вченими, стали витоками і основою всіх суспільно-правових відносин, закріплення обов'язку держави захищати права і свободи людини, створили необхідні передумови для формування в суспільстві вимог гарантованості прав і свобод та поступового їх доповнення новими принципами та інститутами

(C) Булавіна С., 2019 
гарантій прав і свобод людини і громадянина.

Ключові слова: гарантії прав і свобод людини і громадянина, Україна, історико-правове дослідження.

Постановка наукової проблеми та їі значення. Історія становлення такого важливого та необхідного самостійного інституту суспільства, а саме, гарантій прав і свобод людини та громадянина - пройшла нелегкий шлях від минулого до сучасності, тим самим вбираючи в себе те раціональне, яке і становить сьогоднішне розуміння гарантій прав і свобод.

Майже третина статей Основного Закону держави присвячена правам і свободам людини та громадянина. Так, в статті 3 Конституції України визначено головний зміст та спрямованість діяльності держави - права і свободи людини та їх гарантії. Бо саме за допомогою гарантованості, права і свободи людини та громадянина набирають реального змісту.

Таким чином, гарантії прав і свобод людини та громадянина, їх широта, реальність, здійсненність виражають не тільки фактичний та юридичний статус особи в суспільстві, а й суть діючої в країні демократії, соціальні можливості, які закладені в самому суспільному ладі. Вони показники зрілості суспільства, його досягнень, тим більше, що на державу та її органи Конституція і закони України покладають обов'язки забезпечення прав і свобод людини та громадянина.

Аналіз досліджень цієї проблеми. Корені сучасних знань про гарантії прав і свобод людини містяться в ідеях стародавніх мислителів Платона, Арістотеля, Сократа, Протагора, Цицерона які в подальшому розвивались у соціально-філософських роздумах Г. Гроція, Дж. Лок-ка, Ш. Монтеск'є, Ж. Руссо та ін.

Не є винятком і погляди представників теоретико-правової думки України, серед них такі як: Павло Русин, Станіслав Оріховський-Роксолан, Інокентій Гізель, Феофан Прокопович, Іван Баптист Шад, Петро Ліницький, Михайло Драгоманов, Максим Ковалевський, Богдан Кістяківський та багато інших [1].

Необхідно відмітити й те, що за останній період в Україні захищено ряд дисертацій, які містять науковий аналіз окремих аспектів по забезпеченню прав і свобод людини та громадянина, зокрема: І. Й. Магновського, О. М. Руднєвої, Л. В. Леонтьєвої, С. П. Добрянський та інші.

Мета й завдання статті. Метою наукової статті стало висвітлення процесу становлення та розвитку вітчизняної історико-правової думки про гарантії прав і свобод людини та громадянина на підставі історичних, загальнолюдських та юридичних явищ.

Виклад основного матеріалу й обгрунтування отриманих результатів дослідження. Права і свободи людини є однією 3 основних проблем багатовікової історико-правової думки, яка розглядалась 3 позиції політичного, морального, філософського, релігійного та юридичного світоглядів. Якою б не була держава за своєю природою, який би режим у ній не панував - права та свободи людини, їх взаємодія з державою завжди складали не тільки теоретичний, релігійний, філософський інтереси, але й прикладний, оскільки без урахування цієї взаємодії неможливо було встановити в суспільстві порядок, необхідний для пануючої еліти або для демократично обраних правителів [1].

У загальній скарбниці історико-правових досліджень проблематики прав і свобод людини та ïx гарантій гідне місце займає спадщина П. Русина (1450-1517рp.). Потребою звернення до його творчості стали пошуки ним змісту людського життя, розуміння людської особистості. Звертаючись до проблем держави і державного правління, Русин наголошував на тому, що правитель повинен бути мудрою людиною мати світлий розум, стверджувати всі права і чесноти, дбати про повагу громадян. В історії вбачав учительку життя та свободи людини, яка і є творцем історії, де історичний процес зумовлюється не Божим промислом, а $є$ діяльністю людей, які беруть безпосередню участь в історичних подіях [2, с. 110-114].

Виходячи з вищевикладеного, можна відмітити певні засади здійснення прав і свобод, а саме, держава повинна слугувати людині, в якій розум кращої половини суспільства збагачений історичними процесами сприятиме становленню тієї ж цивілізованої держави, де будуть утверджуватись права та свободи людей.

Цікавими та прогресивними ідеями, які сприяють закріпленню прав і свобод людини насичена творчість типового представника українського гуманістичного руху першої половини XVIcт. - філософа, історика та політолога С. Оріховського-Роксолана (1513-1566 pp.), якого колеги називали «русинським (українським) Демосфеном, сучасним Ціцероном». Звертаючись до польської шляхти, Оріховський говорить, що справедливі закони «... є законами вашої свободи, вашої гідності і величі». Право та закони взаємопов'язані зі свободою і є запорукою останньої [3, с. 208]. Зауважимо 
той факт, при якому держава визнається гарантом людини і має обов'язки перед нею, що приводить до зворотного зв'язку, коли і в громадянина з'являються обов'язки перед суспільством, які спрямовані на підтримку існування та розвитку держави. Тобто умовою можливості набути державного статусу гаранта прав і свобод людини та громадянина $\epsilon$ активна діяльність громадян із формування у державі такої якості [3, с. 52].

Певні ідеї зародження прав і свобод людини закладенні у творчій спадщині Інокентія Гізеля (1600-1683 рр.). Одним 3 перших серед вітчизняних мислителів Гізель поставив природне право як критерій людської поведінки вище від закону Божого, доповнюючи критерій добра і зла розумом, який, пізнавши закони природи, керує вчинками людини відповідно до цих законів, що, власне, і відбилося в його ставленні до раніше названих церковних заповідей та настанов $[4$, с. 25$]$.

Проблема свободи людини постала у дослідженнях Теофана Прокоповича (1677-1736 рр.), справжнє прізвище - Єлісей Церейський. Як професор Києво-Могилянської академії Т. Прокопович спрямовував свою діяльність на рішучу боротьбу за перебудову й очищення розуму людини від примар і перешкод для завоювання справжньої істини. Вчений прагнув звільнити природознавство, історію, літературу від схоластичних канонів. Підтримував вчення Галілея, Коперника, виступав за право кожного пізнавати і захищати істину. Підтримуючи розвиток науки, ремесла, мистецтва вводячи гуманістичні світські елементи в освіту, Прокопович ще не наважувався заперечувати божественного творення людини, проте робив спроби показати, що людина велична і славна своїм розумом, чеснотами незалежно від божества [1]. Людина за Прокоповичем, сповнена гідності і значимості у Всесвіті. Всі достоїнства та чесноти розділені в природі, в ній одній зосереджені. Він вважав, що основою діяльності людини має бути активність, чесність, порядність, добросовісність у виконанні своїх обов'язків [5]. Вчений звеличує просту людину, заявляючи, що звичайна проста людина знаходить своє місце в світі, де праця і особисті заслуги є критеріями іiі честі та гідності [6, c. 332].

Еволюційний аналіз розуміння сутності прав й свобод людини та їх гарантій привів до опрацювання творчої спадщини професора Петра Івановича Ліницького. Як і більшість представників академічної філософії в Україні П. Ліницький дотримувався ідеалістичних поглядів. Його ставлення до філософії як до справи розуму людського, вираження самосвідомості, де кожний наступний етап досліджень розкриває нові сторони поставлених питань і шляхів їх розв'язання, визначило світоглядне розуміння сутності людини та її зв'язків з оточуючим світом [7, с. 49].

Відчутним поштовхом у подальшому розвитку проблематики прав та свобод людини i громадянина та їх гарантій була діяльність видатного українського мислителя та громадського діяча Михайла Петровича Драгоманова (1841-1895 рр.) - автора понад двох тисяч наукових праць, державно-правові ідеї якого $є$ виразом «професійно-юридичного погляду на державу, право i політичну організацію суспільства» [8, с. 10].

Пріоритет прав людини можна вважати ядром конституційно-правової доктрини Драгоманова тому, що з нею узгоджуються усі інші положення доктрини, зокрема, конституційні принципи та інститути державного будівництва, місцевого і загальнодержавного самоврядування, федералізму і децентралізації. Основою всього постає людська особистість у своєму прагненні до свободи та добробуту.

Поширення державно-правових ідей, які спрямовані на здійснення прав і свобод людини в українській історико-правовій думці пов'язується з представником класичного лібералізму Максимом Максимовичем Ковалевським (1851-1916 рр.) російським і українським правознавцем, істориком, який відомий своїми порівняльно-правовими дослідженнями виникнення держави i права та закономірностями їх розвитку. Вчений ставився до держави як до своєрідного каркасу безпеки, засобу забезпечення перешкоди хаосу і захисту тих, хто ії створює. Осягаючи зміст свободи людини та сфери впливу держави, М. Ковалевський дійшов висновку і наголосив на необхідності обмеження «деспотії держави», іiї безконтрольного втручання в життя суспільства, коригування «волі індивіда», «права людського» відповідно до своїх інтересів. 3 огляду на це сфера впливу держави мала б обмежуватись сферою «автономії» людської особистості [1]

Необхідно звернути увагу на такий важливий компонент складової забезпечення свободи, як неможливість скасування прав і свобод громадян, на якому зупиняється вчений. На його думку мова йде про гарантії недоторканності цих настанов. Вказана гарантія може існувати виключно за умови, коли «Конституції і перераховані нею публічні права громадян поставлені вище законів» [9, с. 758]. У даному випадку мова йде про передбачення механізму недоторканності конституційних прав і свобод при прийнятті нових законів. Таким чином, державноправові положення М.Ковалевського якісно збагатили розуміння суті явища гарантій прав і свобод людини та громадянина. 
Наступним якісним кроком розвитку розуміння правового стану людини, iї співіснування та співвідносин 3 суспільством і державою стало філософсько-правове дослідження Богдана Кістяківського (1868-1920pр.), українського юриста, теоретика правової держави та філософії права. Основну увагу він приділяв розгляду духовних настанов окремої людини в галузі суспільнополітичного життя і права, що власне і стало базою його теорії закону та правової держави, концепції демократії. Обгрунтовуючи свою теорію законності і правової держави Кістяківський виходив 3 примату панування закону над всіма приватними, особистими i груповими інтересами, неправомірності пояснення закону з точки зору командної, довільної або інструментальної теорії позитивного (історичного) права, вважаючи абсолютно справедливою концепцію природного права 3 його утвердженням невідчужених довічних прав людини, їх незалежності від держави [1].

Відстоюючи пріоритет прав особи та рівність громадян у правах, Кістяківський вважав, що лише це $\epsilon$ передумовою міцного правопорядку. У статті «На захист права» він пише, що головний $\mathrm{i}$ найсуттєвіший зміст права складає свобода. Щоправда, ця свобода окреслюється як зовнішня, відносна, обумовлена суспільним середовищем. Але внутрішня, більш безвідносна, духовна свобода можлива лише за наявності свободи зовнішньої [10, с. 122-123]. Вищевказане твердження вченого призводить до певних міркувань, а саме, визнання притаманності людині природних прав і свобод, перетворення їх у джерело всіх існуючих суспільних та державно-правових стосунків починається 3 опанування певною соціальною культурою, яка складається 3 відтворення пробудженої самосвідомості людини і опанування своєю особистістю [11, с. 619].

Необхідно відмітити і ті фактори у історико-правовій спадщині Б. Кістяківського, які доповнюють уяву про гарантії прав і свобод людини та громадянина і сприяють їх становлення в сьогоденні. Поміж них можна виділити: пріоритет прав і свобод людини як основу формування відносин у державі; визнання єдиним джерелом правових стосунків у державі природних невід'ємних прав і свобод; самоусвідомлення людиною своєї особистості; реалізація прав і свобод через становлення народом державних інститутів влади; розвиток суспільства через зростання рівня правосвідомості його громадян [1].

Отже, поглиблення та поширення теоретичних досліджень та ідей правової держави, правової свідомості, недоторканності людини, iї прав і свобод стали стрижнем історико-правових поглядів мислителя. Підсумовуючи вищевикладені погляди відомих українських вчених, мислителів, істориків, правознавців необхідно відмітити їхній прогресивний внесок, у процес становлення та розвитку ідеї про гарантії прав і свобод людини та громадянина, який приніс й розвинув гуманістичні погляди на людину, що постає як вища у своїй самореалізації особистість, яка злита зі світом природи і одночасно розширює природні засади свого буття. [12, с. 29]. I носієм такої політики має стати держава, що забезпечує права та свободи своїх громадян і тим самим виступає їх гарантом.

Висновки. Таким чином, проведене дослідження дало можливість підсумувати те, що гарантії прав і свобод людини складають самостійне соціально-правове явище, яке має індивідуальні витоки, персональні форми відтворення, особисті принципи і закони становлення, існування та розвитку. А держава, право, суспільство і людина як складові гарантій прав і свобод в свою чергу мають певні ознаки, завдяки яким i можуть виступати гарантами прав і свобод людини та громадянина [1].

\section{Джерела та література}

1. Магновський І. Й. Гарантії прав і свобод людини та громадянина в праві України (теоретикоправовий аспект): дис.к.ю.н., 12.00.01 / I. Й. Магновський; Національна академія внутрішніх справ України. - К., 2003. - 193с.

2. Русин П. Вибрані твори // Українська поезія XVI ст.. - К.: Рад. письменник, 1987. - 287 с.

3. Українські гуманісти епохи Відродження: Антологія. У 2-х частинах. - Ч. 1. / Відп. ред. В. М. Нічик: Ін-т філософії НАН України. - К.: Наукова думка, 1995. - 431 с.

4. Рогович М. Д. Філософія в Києво-Могилянській академії: Інокентій Гізель // Філософська думка. 1970. - №1. - С. 100-101.

5. Самарин Ю. Ф. Стефан Яворский и Феофан Прокопович // Сочинения. - Т. 5. - М.: Типография А.И. Мамонтова и Ко, 1880. -463 с.

6. Історія філософії на Україні: У 3-х т. - Т.1. / Ін-т філософії АН УРСР. - К.: Наукова думка. - 399 с. 7. Линицкий П. И. Платон - представитель идеализма в древней философии // Труды Киевской духовной академии. - Т.3. - К., 1868. - 195 с. 
8. Сокуренко В. Г. Демократическое учение о государстве и праве на Украине во второй половине XIX века (М. Драгоманов, С. Подолинский, О. Терлецкий). - Львов: Изд. Львовского ун-та, 1996. $265 \mathrm{c}$.

9. Ковалевский М. Государственное право европейских государств (1883) // История политических и правовых учений: хрестоматия для юридических вузов и факультетов / Под общ. ред. Г. Г. Демиденко. - Х.: Факт, 1999. - 1079 с.

10. Кистяковский Б. В защиту права интеллигенции и правосознание / Б. Кистяковский // Вехи: из глубины [сб. ст. о рус. революции]; предисл. В. Шелохаева. - М.: Мол.гвардия, 1991. - 461 с.

11. Кистяковскій Б. А. Социальныя науки и право. Очерки по методологии социальныхъ наукъ и общей теоріи права. - М.: Изд. М. и С. Собашниковыхъ, 1916. - 704 с.

12. Скиба В., Горбатенко В., Туренко В. Вступ до політології: екскурс в історію правничо-політичної думки / В. Скиба, В. Горбатенко, В. Туренко. - К.: Основи, 1998. - 718 с.

Булавина С. Генезис гарантий прав и свобод человека и гражданина в Украине: историко-правовое исследование. В статье исследовано современное состояние историко-правовой мысли о гарантиях прав и свобод человека и гражданина. Выявлено становление и развитие идеи гарантий прав и свобод человека и гражданина в Украине. В отечественной сокровищнице историкоправовых исследований по проблематике прав и свобод человека и их гарантий достойное место занимает наследие Павла Русина (1450-1517 гг.). Интересными и прогрессивными идеями, которые способствовали закреплению прав и свобод человека, насыщено творчество типичного представителя украинского гуманистического движения первой половины XVIст. философа, историка и политолога Станисловав Ориховского-Роксолана (1513-1566 гг.). Одним из первых среди отечественных мыслителей Иннокентий Гизель (1600-1683 гг.) поставил естественное право как критерий человеческого поведения выше закона Божьего, дополняя критерий добра и зла разумом, который, познав законы природы, руководит поступками человека в соответствии с этими законами. Установлено, что на государство и его органы Конституция и законы Украины возлагают обязанности по обеспечению прав и свобод человека и гражданина. Исследовав воззрения и идеи представителей отечественной историко-правовой науки, следует в целом признать их несомненный вклад в процесс становления и развития такой правовой категории, как гарантии прав и свобод человека и гражданина. Этому предшествовал сложный и длительный путь возникновения и развития идеи о правах и свободах человека и гражданина и их гарантиях. Историко-правовые идеи, выдвинутые выдающимися учеными, стали истоками и основой всех общественно-правовых отношений, закреплениея обязанности государства защищать права и свободы человека, создали необходимые предпосылки для формирования в обществе требований гарантированности прав и свобод и постепенного их дополнения новыми принципами и институтами гарантий прав и свобод человека и гражданина.

Ключевые слова: гарантии прав и свобод человека и гражданина, Украина, историкоправовое исследование.

Bulavina S. Genesis of the Guarantees of the Human Rights and Freedoms of Citizens in Ukraine: Historical and Legal Aspects. The article elucidates historical and legal views on the guarantees of the rights and freedoms of citizens, with a focus on the formation and development of the idea of guarantees of human and citizen's rights and freedoms in Ukraine. In the greatest treasury of historical and legal research of human rights and freedoms and their guarantees, a worthy place is occupied by the legacy of Pavlo Rusyn (1450-1517). The work of a typical representative of the Ukrainian humanist movement of the first half of the 16th century, philosopher, historian and political scientist Stanislav Orikhovsky-Roksolan (1513-1566) is full of interesting and progressive ideas that contribute to the consolidation of human rights and freedoms. Innocentiy Gizel (1600-1683) was one of the first among domestic thinkers, who put natural law as a criterion of human behavior above the law of God, complementing the criterion of good and evil by reason, which, knowing the laws of nature, governs human actions in accordance with these laws. The author states that the responsibilities for the protection of human and citizen's rights and freedoms are vested in the Constitution, the state and its bodies, and the laws of Ukraine. Considering the thoughts and ideas of the representatives of the national historical and legal heritage, scholars point to their unprecedented contribution to the process of formation and development of such historical and legal category as guarantees of human rights and freedoms of citizens. It was preceded by a long and difficult way of origin and development of the idea of human and citizen's rights and freedoms and their guarantees. Historical and legal ideas, put forward 
by prominent scientists, were the origins and foundation of all social and legal relations, consolidated the obligation of the state to protect the rights and freedoms, having created the necessary prerequisites for the formation of the society requirements to secure the rights and freedoms, with gradual addition of new principles and institutions to guarantee these rights and freedoms.

Key words: guarantees of human rights and freedoms of citizens, Ukraine, historical and legal research.

УДК 94(477)

DOI https://doi.org/10.32782/2409-4544/2019-2/3

В. Колодяэниа

\section{Формуваня та розвиток джерел міського права Луцька у складі Волинсько-Галицької держави та Великого князівства Литовського}

У статті зроблено аналіз формування та розвитку джерел права і інститутів самоврядування Луцька в складі різних держав, досліджена спадкоємність розвитку норм місцевого права на етнічних українських землях, сформованого за часів Київської Русі, Волинсько-Галицької держави і в процесі інкорпорації зарубіжних (німецьких, польських) елементів правового досвіду формування $\mathrm{i}$ функціонування державно-правових інститутів і місцевого самоврядування на Волині в кінці XIIIXVII ст. До основних джерел міського права протягом XIII-XVII ст. відносяться такі первинні нормативні акти: «Руська правда»; грамоти і привілеї про надання місту магдебурзького права 1432, 1497, 1503, 1560, 1576 рр.; статутні грамоти 1501, 1509, 1547 рр.; Жалувана грамота 1457 р.; Судебник 1468 р.; Статут Великого князівства Литовського 1529 р. і його редакції 1566 і 1588 р.p.; збірники магдебурзького права; а похідними від перших - акти органів самоврядування, цехів i судова практика. Особливе місце серед джерел міського права Луцька займає Статут Великого князівства Литовського 1529 р. Цей кодифікований нормативний акт дав новий поштовх до розвитку литовсько-руського права взагалі, і міського права безпосередньо на території усього князівства. Місцеве самоврядування України пройшло складний та досить суперечливий історичний шлях. Започатковані ще у період Київської Русі елементи управління протягом століть постійно зазнавали впливу східної та західної політичних культур, що пояснювалося особливим геополітичним розміщенням держави. Цим пояснюється і особливість формування джерел права середньовічних міст Волинсько-Галицької держави і Великого князівства Литовського, і Луцька, зокрема.

Ключові слова: джерела права, муніципальне право, Магдебурзьке право, ВолинськоГалицьке князівство, Велике князівство Литовське.

Постановка наукової проблеми та їі значення. Для історично-правових досліджень міських громад і міського права останніх років характерне істотне накопичення фактичного матеріалу, аналіз якого утвердив історію громад і муніципального права як окрему сферу наукового пізнання.

У цьому контексті надзвичайно важливим $\epsilon$ дослідження розвитку джерел права середньовічного міста та функціонування на їх основі інститутів місцевого самоврядування, які формували суспільство нового типу в різних регіонах держави i, зокрема, Волині, у складі різних держав у період Середньовіччя та ранньомодерного часу. Це і становить мету і завдання статті.

Виклад основного матеріалу й обгрунтування отриманих результатів дослідження. На початку ХІ століття (1016-1036 рр.) світ побачила Руська Правда, судебник Київської Русі. Вона мала величезне значення для подальшого розвитку українського, російського, білоруського і литовського права [1, с. 56]. У Волинсько-Галицькій державі як правонаступниці Київської Русі в різні часи діяли відомі редакції Руської правди: Коротка, Поширена та Скорочена. Застосування норм Руської правди в Галицько-Волинському князівстві не мало яскраво виражених відмінностей. Руська правда не втратила свого значення з розпадом України-Русі. Ї̈̈ норми знайшли своє відображення у ІІ Статуті Великого князівства Литовського, чинному в Волинсько-Галицькій землі і відомому під назвою Волинського [4, с. 8].

(C) Колодяжна В., 2019 